\title{
Nutri-Priming as an Efficient Means to Improve Germination and Growth of Mung bean (Vigna radiata L.) Grown Under NaCl Stress
}

\author{
Rashid Abbas Khan ${ }^{1}$, Zahra Noreen ${ }^{1 *}$, Amjid $\mathrm{Khan}^{2}$ and Tauqeer \\ Ahmed Qadri ${ }^{3}$ \\ 1. Department of Botany, University of Education, Lahore-Pakistan \\ 2. Department of Botany, University of Mianwali, Punjab-Pakistan \\ 3. Department of Biosciences, University of Wah, Wah Cantt-Pakistan \\ *Corresponding author's email: zahranoreen@gmail.com \\ Citation
}

Rashid Abbas Khan, Zahra Noreen, Amjid Khan, Tauqeer Ahmed Qadri. Nutri-priming as an efficient means to improve germination and growth of Mung bean (Vigna radiata L.) grown under NaCl stress. Pure and Applied Biology. Vol. 10, Issue 1, pp34-45. http://dx.doi.org/10.19045/bspab.2021.100005

\begin{tabular}{llll}
\hline \hline Received: 19/05/2020 & Revised: 05/08/2020 & Accepted: 15/08/2020 & Online First: 26/08/2020 \\
\hline \hline
\end{tabular}

\section{Abstract}

Salinity is a major environmental issue that reduced the crop growth and productivity. The micronutrients like $\mathrm{Zn}$ have the potential to decrease the toxic effects of salinity. The recent study was conducted to examine to effect of $\mathrm{ZnSO}_{4}$ on germination percentage, physiological, biochemical attributes and antioxidant enzymes (CAT, POD, SOD) activities of Vigna radiata L. The seeds were primed with two (100ppm and 200ppm) concentrations of $\mathrm{ZnSO}_{4}$ and then grown under various levels of $\mathrm{NaCl}(0-50-75-100 \mathrm{mM})$ stress. The results indicated that various physiological, morphological and biochemical parameters negatively influenced by salt stress. However, the nutripriming with $\mathrm{ZnSO}_{4}$ enhanced the germination percentage and growth of Vigna radiata under $\mathrm{NaCl}$ stress. The comparison of both concentrations showed that 100ppm improved the morphological parameters (root, shoot length, fresh and dry weight of root, shoot) and Biochemical parameters (proline and total soluble protein), While the nutripriming with 200ppm improved the chlorophyll (a \& b), phenolics and flavonoids contents more than control. The Zn application improves the Antioxidant enzymes (CAT, POD, SOD) but at higher doses cause reduction. This is environment friendly technique and can be used in future.

Keywords; Flavonoids; Protein; Proline; Seed priming; Salinity; $\mathrm{ZnSO}_{4}$

\section{Introduction}

Mung bean (Vigna radiata L.) is one of the most important food crops in Pakistan. It is a legume crop with higher contents of proteins and short summer season crop. The mung bean can be used as an export potential crop [1]. Mung bean is the member of family Fabaceae and genus Vigna. Mung bean in Pakistan is being cultivated on 146,000 hectares with annual
98,000 tons of production, marginal yield per unit area [2].

The salinity reduced the growth rate and yield of agricultural crops more than other environmental factors [3]. The abiotic stress negatively influenced the development and yield of many crops [4]. The higher levels of salt stress caused adverse effects on growth and yield of crops [5]. More than $800 \mathrm{million} / \mathrm{hectors}$ 
land are badly influenced by salt stress through the world [6].

However, the micronutrients have the potential to reduce the salinity. The most well-known strategies for micronutrient application are foliar application, seed treatment and soil application. The nutripriming is a basic priming strategy in which seeds are absorbed soaked in aerated solution of nutrients [7]. Since micronutrients are required in smaller amounts, priming in solutions with higher concentrations may cause seed damage and poor germination. Therefore, concentration of nutrient solution is to be optimized before field testing [8].

Zinc in the earth crust naturally occurs at 70 $\mathrm{mg} / \mathrm{kg}$, which ranges between 10 to 300 $\mathrm{mg} / \mathrm{kg}$. It is usually estimated about $30 \%$ Zinc is produced from recycled products. The industrial movement has brought about anthropogenic contribution of zinc to the earth [9]. Zinc is absorbed by the roots as divalent cation $\left(\mathrm{zn}^{2+}\right)$. $\mathrm{Zn}$ activates many enzymes like alcohol dehydrogenase $(\mathrm{ADH})$ and carbonic anhydrase (CA). While deficiency of $\mathrm{Zn}$ in soil cause changes in metabolism of the auxin hormone. The $\mathrm{Zn}$ availability in soil depends on soil $\mathrm{pH}$, presence of micro and macronutrients and soil microorganisms. Their intersection among themselves makes the $\mathrm{Zn}$ available and non-available. While increase in soil $\mathrm{pH}$ causes the less solubility in soil and its uptake also deceased [10]. Zinc plays essential role in chlorophyll synthesis [11]. The objectives of the recent study are to standardize the methodology of nutripriming of Vigna radiata $\mathrm{L}$. with $\mathrm{ZnSO}_{4}$, to examine the role of micronutrients on germination, growth, and biochemical aspects grown under salt stress.

\section{Materials and Methods \\ Collection of seeds}

The seeds of Mung bean (Vigna radiata L. cv. Chakwal) were collected from NARC (National Agriculture Research Center Islamabad).

\section{Experimental design}

The seeds were surface sterilized for 30 seconds with $70 \%$ ethanol and then washed with distilled water. The seeds were primed for 1-hour with 100ppm and 200ppm $\mathrm{ZnSO}_{4}$ and then seeds were dried. Later the seeds were sown under $\mathrm{NaCl}$ (0-50-75$100 \mathrm{mM} \mathrm{NaCl})$ stress. The experiment was placed with 3 replicates and total 36 pots were used. The germination percentage were observed after 24 hours up to 7 days to count constant percentage of germination. The plants of Vigna radiata $\mathrm{L}$. were harvested and length of shoot, root was measured with simple ruler, while the fresh and dry weight of root, shoot was measured with electronic measuring balance.

\section{Antioxidant enzymes}

The method of Beauchamp and Fridovich [12] was followed to determine the Superoxide dismutase (SOD) activity, protocol of [13] for Peroxidase (POD) activity and method of [14] was used for estimation of Catalase activity.

\section{Biochemical analysis}

The protocol of [15] and the following equation were used to calculate the chlorophyll a and chlorophyll b. The contents of proline in leaves of Vigna radiata $\mathrm{L}$. were determined by the method of [16] and phenolic contents were estimated using the protocol of [17]. The flavonoids were estimated by following the method of [18] by using $\mathrm{AlCl}_{3}$ protocol. The total soluble protein was determined by using the protocol of [19] and final calculation was done by using following equation;

Protein $(\mathrm{mg} / \mathrm{g})=\mathrm{OD} \times \mathrm{K}$ value $\times$ Dilution Factor/ sample weight

$\mathrm{K}$ value $=19.6$

\section{Results and Discussion}

The results mentioned in (Table 1) indicated that germination percentage strongly reduced under salt stress. The germination percentage significantly $(\mathrm{P}<0.05)$ reduced under $\mathrm{NaCl}$ stress. Our findings are in consistence with the [20, 21]. The reduction in germination is related 
to salinity disturbances with the metabolic process causing increase in phenolic compounds. The reduction in germination is also due to reduced water movement into seed during imbibition's [20]. Salt stress influenced the seed germination through osmotic effects [22]. However, nutripriming with $\mathrm{ZnSO}_{4}$ enhanced the seed gemination under $\mathrm{NaCl}$ stress. The nutripriming with $\mathrm{ZnSO}_{4}$ increased the germination percentage more than control plants under $\mathrm{NaCl}$ stress, while comparison of 100ppm and 200ppm showed that higher levels of $\mathrm{Zn}$ also inhibit the germination percentage. The significantly $(\mathrm{P}<0.005)$ highest germination percentage were observed at $100 \mathrm{ppm}$ under $50 \mathrm{~m} \mathrm{MNaCl}$.
The higher emergence was results of reduced.

Physiological non-uniformity in seeds due to priming. Our results are in consistence with the findings of $[23,24]$, they reported that priming of seeds enhanced the germination rate, faster seedlings emergence and early germination. The nutripriming with Zinc enhanced the germination and seedling growth in barley reported by [25], while the higher concentrations of $\mathrm{Zn}$ reduced the germination percentage as reported by $[4$, 26]. The reduction in germination percentage under higher doses of Zinc were also reported in Vigna mungo (variety T-9) by [27] and on Sesuvium portulacastrum by [28].

Table 1. Effect of nutripriming with $\mathrm{ZnSO}_{4}$ on germination percentage of Vigna radiata L. under $\mathrm{NaCl}$ stress $(n=3$, mean \pm value $\mathrm{SE})$

\begin{tabular}{|c|c|c|c|c|}
\hline Treatments & $\mathbf{0 ~} \mathbf{~ m M}$ & $\mathbf{5 0} \mathbf{~ m M}$ & $\mathbf{7 5} \mathbf{~ m M}$ & $\mathbf{1 0 0} \mathbf{~ m M}$ \\
\hline Control & $\mathrm{a} 85.71 \pm 8.25$ & $\mathrm{~b} 76.18 \pm 4.76$ & $\mathrm{~b} 71.42 \pm 0.00$ & $\mathrm{~b} 65.66 \pm 4.76$ \\
\hline ZnSO $_{\mathbf{4}}$ 100ppm & $\mathrm{a} 95.23 \pm 4.76$ & $\mathrm{a} 100 \pm 0.00$ & $\mathrm{a} 95.23 \pm 4.76$ & $\mathrm{a} 85.71 \pm 0.00$ \\
\hline ZnSO $_{\mathbf{2}} \mathbf{2 0 0 p p m}$ & $\mathrm{a} 95.23 \pm 4.76$ & $\mathrm{ab} 90.47 \pm 4.76$ & $\mathrm{ab} 85.71 \pm 8.25$ & $\mathrm{ab} 80.94 \pm 4.76$ \\
\hline
\end{tabular}

The results mentioned in fig. 1A showed that salt stress negatively influenced the shoot length. The shoot length of Vigna radiata $\mathrm{L}$. significantly $(\mathrm{P}<0.05)$ reduced under $\mathrm{NaCl}$ stress. Our findings are in consistence with $[29,30]$. The reduced growth of shoot may be because of injurious effects of sodium chloride and unbalanced uptake of nutrients by plants. The higher levels of salt stress Inhibit shoot and root elongation by disturbance in water uptake by plant. However, the nutripriming with $\quad \mathrm{ZnSO}_{4} \quad$ significantly $\quad(\mathrm{P}<0.05)$ increased the shoot length under $\mathrm{NaCl}$ stress. While the comparison of $100 \mathrm{ppm}$ and 200ppm showed that $\mathrm{Zn}$ at lower levels improves the plant growth but at higher concentration proves toxic and disturbs the plants growth. The maximum significant $(\mathrm{P}<0.05)$ values of shoot length $(35.50 \pm 0.12)$ were observed at $100 \mathrm{ppm}$ under $50 \mathrm{mM} \mathrm{NaCl}$. Zinc sulphate generally inhibits physiological processes. As zinc interference with the activities of many enzymes essential for normal development and metabolic processes and due to its direct interaction with proteins pigments, etc. [31]. $\mathrm{Zn}$ is an important micronutrient for plant growth, but extent amounts proves toxic and can disturbs the normal biological processes [32]. The lower doses of $\mathrm{Zn}$ improved the plant growth but at higher concentrations reduction in plant growth were found [33].

The findings of present study mentioned in fig. 1B indicated that fresh weight of shoot significantly $(\mathrm{P}<0.05)$ decreased under increased levels of various salt stress. The findings of recent study are in consistence with [34], they found that salinity lowers the fresh weight of pumpkin genotypes. However, the nutripriming with $\mathrm{ZnSO}_{4}$ significantly $(\mathrm{P}<0.05)$ improved fresh biomass of shoot under $\mathrm{NaCl}$ stress. The comparison of $100 \mathrm{ppm}$ and 200ppm showed that higher levels of $\mathrm{Zn}$ proves toxic, while the highest value $(25.37 \pm 0.32)$ of shoot fresh weight was found at 100ppm under $50 \mathrm{mM} \mathrm{NaCl}$. Zinc at lower concentration improves the germination, 
fresh and dry weight over the control and $\mathrm{Zn}$ at lower concentrations role as a significant stimulatory, beneficiary and nutritional micronutrient. $\mathrm{Zn}$ treatment improves the shoot length and shoot weight of soybean grown under $\mathrm{NaCl}$ stress [9]. The higher doses of $\mathrm{Zn}$ lower the root, shoot fresh and dry weight [35].

The findings of recent study mentioned in fig. 1C showed that salt stress strongly influenced the shoot dry weight. There was a significant $(\mathrm{P}<0.05)$ reduction in the shoot dry weight under $\mathrm{NaCl}$ stress. Our findings are supported by [30]. However, the nutripriming with $\mathrm{ZnSO}_{4}$ promoted dry weight of shoot under various levels of $\mathrm{NaCl}$. The comparison of 100ppm and 200ppm showed that nutripriming with $\mathrm{ZnSO}_{4}$ at $100 \mathrm{ppm}$ promoted this parameter more than control and priming with $200 \mathrm{ppm}$. The significant $(\mathrm{P}<0.05)$ highest $(8.47 \pm 0.06)$ values of shoot dry weight were found at $100 \mathrm{ppm}$ under $50 \mathrm{mM} \mathrm{NaCl}$. Which showed that Nutripriming with $\mathrm{Zn}$ improves the plant growth at lower levels, but higher levels of $\mathrm{Zn}$ caused detrimental effects over plants. Our results are in conformity with $[35,36]$, they reported that Zinc improves fresh and dry weight and proline contents.

The findings mentioned in fig. 1D showed that root length of Vigna radiata $\mathrm{L}$. is negatively influenced by salt stress. The root length significantly $(\mathrm{P}<0.05)$ reduced under $\mathrm{NaCl}$ stress. The decrease in root length under various levels of $\mathrm{NaCl}$ were also described by [29, 30]. Salt stress inhibit the root growth more than shoot, as roots are directly contacted to soil and absorbs water and supply to rest of plants [37]. However, the nutripriming with $\mathrm{ZnSO}_{4}$ significantly $(\mathrm{P}<0.05)$ improved the root length under $\mathrm{NaCl}$ stress. The comparison of $100 \mathrm{ppm}$ and 200ppm showed that the nutripriming with $100 \mathrm{ppm}$ promoted the root length under $\mathrm{NaCl}$ stress more as compared to priming with 200ppm and control plants. The significant $(\mathrm{P}<0.05)$ maximum values of root length $(20.33 \pm 1.26)$ were found at $100 \mathrm{ppm}$ under
$0 \mathrm{mM} \mathrm{NaCl}$ stress. Which showed that higher concentrations of $\mathrm{Zn}$ caused injurious effects. At lower concentration it improves the plant growth but higher doses reduction in plant growth were found [33]. The results mentioned in fig. $1 \mathrm{E}$ showed that there was a significant $(\mathrm{P}<0.05)$ reduction in fresh weight of root under $\mathrm{NaCl}$ stress. The salt stress negatively influenced the rot fresh weight and minimum values were observed at higher level $(100 \mathrm{mM})$ of $\mathrm{NaCl}$. Our findings are in conformity with [30]. However, the nutripriming with $\mathrm{ZnSO}_{4}$ enhanced the root fresh weight under salt stress. The comparison of both (100ppm \& 200ppm) concentration showed that $100 \mathrm{ppm}$ improved the root dry weight more than $200 \mathrm{ppm}$. The significant $(\mathrm{P}<0.05)$ higher fresh weight of root was found $(4.09 \pm 0.036)$ at $100 \mathrm{ppm}$ under $0 \mathrm{mM} \mathrm{NaCl}$. Our findings are in consistence with $[9,35$, 36].

The results mentioned in fig. $1 \mathrm{~F}$ indicated root dry weight is strongly reduced under $\mathrm{NaCl}$ stress. The higher levels of salt stress significantly $(\mathrm{P}<0.05)$ decrease the dry weight of root. Our results are supported with the findings of [30]. While the nutripriming with $\mathrm{Zn}$ improves the dry weight of root of Vigna radiata under salt stress. The comparison of 100ppm and $200 \mathrm{ppm}$ sowed that nutripriming with $100 \mathrm{ppm} \quad \mathrm{ZnSO}_{4}$ significantly $\quad(\mathrm{P}<0.05)$ improved dry weight of root more as compared to 200ppm under salt stress. The higher levels of $\mathrm{Zn}$ also cause reduction in root length and in return fresh and dry weight of root. $[9,36]$.

The results mentioned in fig. 2A\& B Showed that photosynthetic pigments decreased at higher levels of salt stress. The higher levels of $\mathrm{NaCl}$ caused toxic effects on chlorophyll (a \& b). The decrease in photosynthetic pigments under $\mathrm{NaCl}$ stress may be because of injurious effects of accumulated $\left(\mathrm{Na}^{+} \& \mathrm{Cl}^{-}\right)$on biosynthesis of pigments and chloroplast structure. In this regard [30] reported that salinity influences the strength of binding forces of pigment- 
protein yield complex in the structure of chloroplast. Salinity also caused swelling of membrane in chloroplast and thus effects the chlorophyll and excess ion in leaves induces loss of chlorophyll [38]. However, the nutripriming with $\mathrm{ZnSO}_{4}$ significantly $(\mathrm{P}<0.05)$ increased chlorophyll $(\mathrm{a} \& \mathrm{~b})$ contents under salt stress. While the comparison of both (100ppm \& 200ppm) concentrations showed that $100 \mathrm{ppm}$ increased the chlorophyll ( $\mathrm{a} \& \mathrm{~b}$ ) contents more as compared to $200 \mathrm{ppm}$ under salt stress. The effects of salt stress were less effective on photosynthetic pigments of plants treated by $\mathrm{Zn}$ and $\mathrm{Zn}$ improve the chlorophyll a, b of Vicia faba (cv. Giza716) reported by [38]. The positive effects of $\mathrm{Zn}$ to improve chlorophylls were also reported by $[36,39]$. $\mathrm{Zn}$ improves the growth and chlorophyll contents of tomato plants under salinity stress $[40,41]$.

The salt stress strongly influenced the proline contents of leaves of Vigna radiata L. The fig. $2 \mathrm{C}$ showed that proline contents are accumulated under salt stress. Our results are supported by the findings of [30], while the [26] suggested that accumulation of proline is used as a sensitive index of susceptibility to water stress. However, in a few plants' species the $\mathrm{NaCl}$ stress stimulated the antioxidative enzymes activities, that showed the role of salt stress in formation of ROS [42].The comparison of both (100ppm \& 200ppm) concentrations showed that $100 \mathrm{ppm}$ significantly $(\mathrm{P}<0.05)$ increased the proline contents under salt stress. The significantly $(\mathrm{P}<0.05)$ higher values of proline contents (76.36 \pm 1.48$)$ were found at $100 \mathrm{ppm}$ under $100 \mathrm{mM} \mathrm{NaCl}$. Proline is accumulated under heavy metals stress and considered too involved in stress resistance [43]. The accumulation of proline helps to utilize the nitrogenous compounds and protects plants against heavy metals stress. The accumulated proline also acts as membrane stabilizing agent under stress [44].

The results mentioned in fig. 2D showed that phenolic contents also accumulated under salt stress. The phenolic contents are directly proportional to salt stress, with the increased $\mathrm{NaCl}$ levels the phenolic contents also increased. While the nutripriming with $\mathrm{Zn}$ improved the phenolic contents under salt stress. The comparison of both (100ppm \& 200ppm) was made and findings showed that 200ppm significantly $(\mathrm{P}<0.05)$ improved the phenolic contents. The significant higher values of phenolic contents $(94.37 \pm 1.24)$ were found at $200 \mathrm{ppm}$ under $100 \mathrm{mM} \mathrm{NaCl}$. Our results are in consistence with $[38,44]$, who reported the role of $\mathrm{Zn}$ to improves the total phenolic contents.

The flavonoid contents are strongly influenced by salt stress. The findings mentioned in fig. $2 \mathrm{E}$ showed that flavonoids contents increased under salt stress. The comparison of both (100ppm \& 200ppm) was made and findings showed that 200ppm significantly $(\mathrm{P}<0.05)$ increased the flavonoids contents. The significant $(\mathrm{P}<0.05)$ higher values of flavonoids contents $(74.18 \pm 1.67)$ were found at 200ppm under $\mathrm{NaCl}$ stress. Our results are in consistence with [1, 38, 44]. The results mentioned in fig. $2 \mathrm{~F}$ showed that total Soluble Protein significantly $(\mathrm{P}<0.05)$ effected by $\mathrm{NaCl}$ stress. It was found that protein is accumulated under salt stress and when the $\mathrm{NaCl}$ levels increased then total soluble protein also increased. While the nutripriming with $\mathrm{ZnSO}_{4}$ reduced the protein in Vigna radiata $\mathrm{L}$. under salt stress. The comparison of both (100ppm \& 200ppm) was made and findings showed that $100 \mathrm{ppm}$ increased the protein contents. The significant $(\mathrm{P}<0.05)$ higher values of protein $(0.432 \pm 0.054)$ were found at $100 \mathrm{ppm}$ under $100 \mathrm{mM} \mathrm{NaCl}$ stress. $\mathrm{Zn}$ has essential role in protein and nucleic acid synthesis and for $\mathrm{N}$ and $\mathrm{P}$ utilization in formation of seed and development [45]. The excess of $\mathrm{Zn}$ decreased the protein because metals bind with the sulfhydryl group of protein causing deleterious effect in the normal protein form [11].

The fig. 3A showed that CAT activity is strongly affected by salinity. It was 
observed that CAT Activity was significantly $(\mathrm{P}<0.05)$ higher in the leaves of plants emerged from the primed seeds grown under salt stress than control plants. While comparison of both (100ppm \& 200ppm) concentrations showed that higher doses of $\mathrm{Zn}$ also cause reduction in the CAT activity. Our results are in conformity with $[46,47]$. The application of $\mathrm{Zn}$ improves the CAT activity, but higher doses of $\mathrm{Zn}$ also cause reeducation in CAT activity as described by [48] in the wheat.

The fig. 3B showed that POD activity is also strongly affected by salinity. It was observed that POD activity significantly increased under salt stress. While comparison of both (100ppm \& 200ppm) concentrations showed that higher doses of $\mathrm{Zn}$ cause reduction in the POD activity. Our results in conformity with $[46,49,50]$. Salt stress is the major cause to increase the concentrations of ROS. Therefore, antioxidant enzymes play significant role to remove destructive oxidant species [47].

The fig. 3C showed that SOD is directly proportional to salt stress. As the salt stress increased the SOD activity also increased. The comparison of both (100ppm \& 200ppm) concentrations showed that higher doses of $\mathrm{Zn}$ cause reduction in the SOD activity. The significant maximum SOD activity was observed at 100ppm under $100 \mathrm{mM}$. Our results in conformity with [50, 51]. Salt stress cause the production of ROS. To reduce the oxidative stress plant, adopt different defensive mechanism like enzymatic and non-enzymatic antioxidant system [52]. The antioxidant enzymes like CAT, SOD and POD are formed by plants to overcome the effects of ROS. The $\mathrm{Zn}$ has efficient role in the formation and activity of antioxidant enzymes, and these are responsible for formation of $\mathrm{OH}^{-}$from $\mathrm{H}_{2} \mathrm{O}_{2}$ and $\mathrm{O}_{2}^{-}[53]$. 

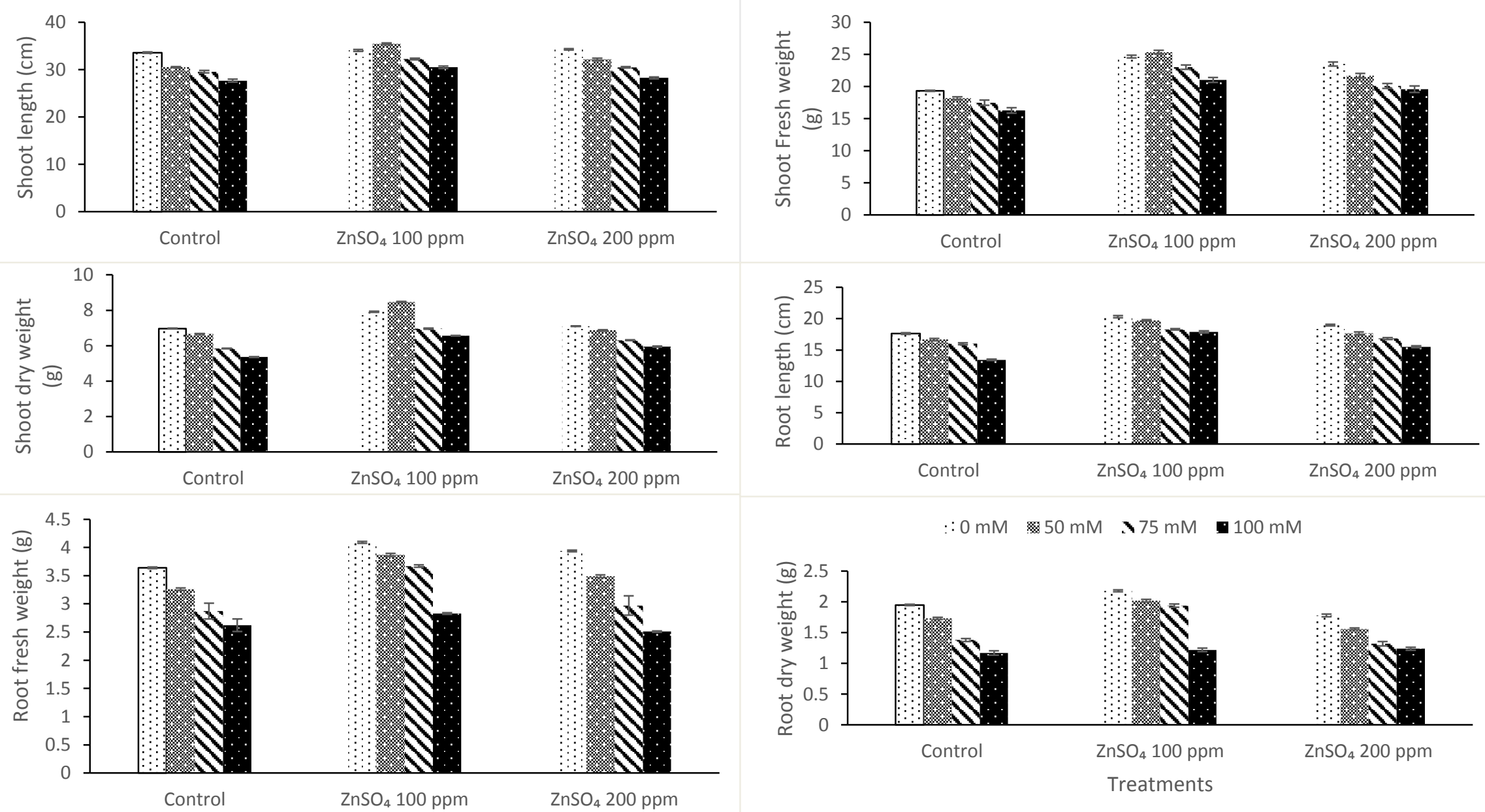

Figure 1. Effect of Nutripriming with $\mathrm{ZnSO}_{4}$ on (A) Shoot length, (B) Shoot fresh weight, (C) Shoot dry weight, (D) Root length, (E) Root fresh weight \& (F) Root dry weight of Vigna radiata L. grown under NaCl (0-50-75-100 mM) Stress 

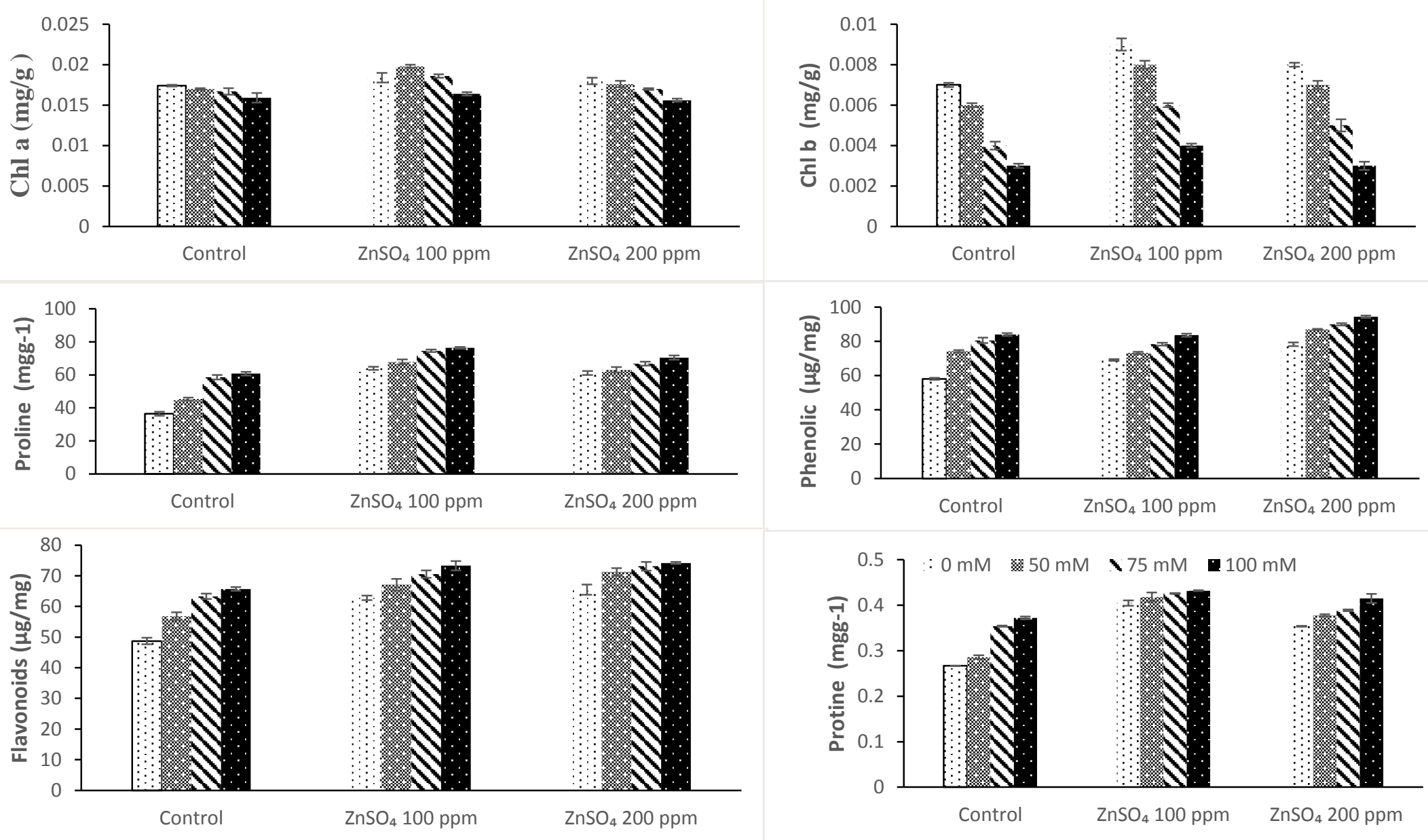

Figure 2. Effect of Nutripriming with (100ppm \& 200ppm) $\mathrm{ZnSO}_{4}$ on (A) Chlorophyll a, (B) Chlorophyll b, (C) Proline, (D) Phenolic contents, (E) Flavonoids \& (F)Total Soluble Protein of Vigna radiata L. grown under NaCl (0-50-75-100 mM) Stress 

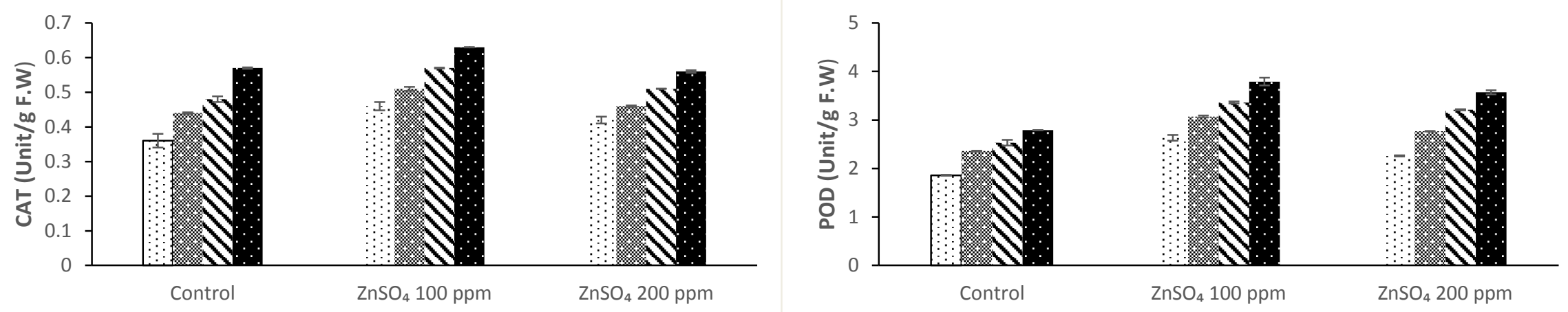

$0 \mathrm{mM}: 50 \mathrm{mM} 、 75 \mathrm{mM}=100 \mathrm{mM}$

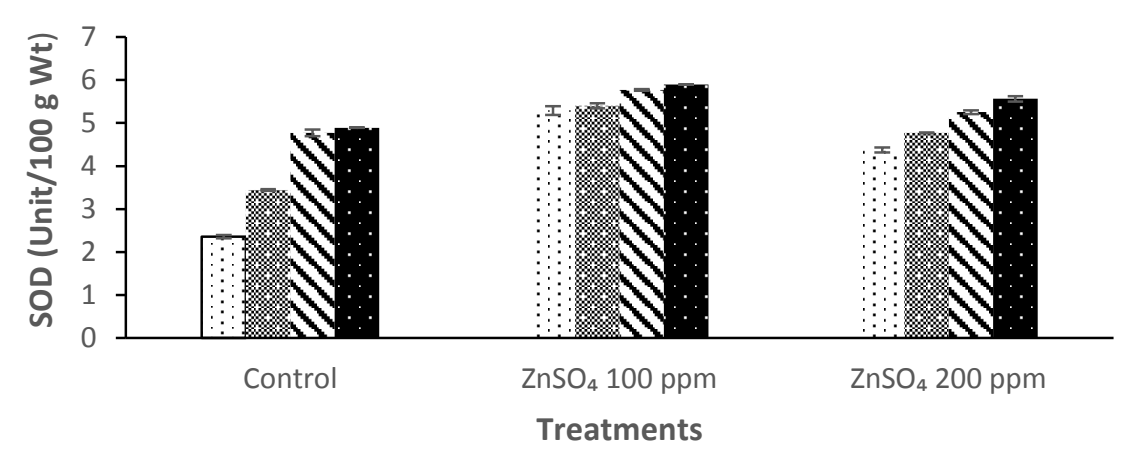

Figure 3. Effect of Nutripriming with (100ppm \& 200ppm) $\mathrm{ZnSO}_{4}$ on (A) CAT, (B) POD, (C) SOD activity of leaves of Vigna radiata L. grown under $\mathrm{NaCl}(0-50-75-100 \mathrm{mM})$ Stress 


\section{Conclusion}

Overall, salt stress negatively influenced the germination and growth of Vigna radiata $\mathrm{L}$. but antioxidant enzymes (CAT, POD, SOD) increased due to salt stress. The nutripriming with $\mathrm{ZnSO}_{4}$ improved the germination percentage, growth parameters (shoot, root length, root, shoot fresh weight and dry weight) and Biochemical aspects (chlorophyll a \& b, proline, protein, phenolics contents and flavonoids contents) under salt stress. Moreover, this is environment friendly technique and can be used in future.

\section{Authors' contributions}

Conceived and designed the experiment work and supervised the research work: Z Noreen, Performed the experiments and wrote article: RA Khan \& TA Qadri, Analysed the data and helped in experiments: A Khan.

\section{References}

1. Khan RA, Khan A \& Qadri TA (2019). Influence of Seed Priming with $\mathrm{FeSO}_{4}$ on Germination, Growth and Biochemical Aspects of Mung bean (Vigna radiata L.) Grown Under $\mathrm{NaCl}$ Stress. J Bio \& Appli Res 5(4):519 -532.

2. Hanif R, Naeem-ud-Din \& Subhani A (2013). Performance based evaluation of different genotypes of mung bean (Vigna radiata) under rainfed conditions of Chakwal. J Agri-Food \& Appl Sci 1:13-15.

3. Ali B, Ali A, Tahir M \& Ali S (2014). Growth, Seed yield and quality of mung bean as influenced by foliar application of iron sulfate. Pak J Life Soc Sci 12(1): 20-25.

4. Ahmed IM, Dai H, Zheng W, Cao F, Zhang G, Sun D \& Wu F (2013). Genotypic differences in physiological characteristics in the tolerance to drought and salinity combined stress between Tibetan wild and cultivated barley. Plant Physiol Biochem 63: 49-60.

5. Ashrafuzzaman M, Khan MH \& Shahidullah SM (2002). Vegetative growth of maize (Zea mays) as affected by a range of salinity. Crop Res 24(2): 286-291.
6. Munns R \& Tester M (2008). Mechanisms of salinity tolerance. Annu Rev Plant Biol 59: 651-681.

7. Farooq M, Wahid A \& Siddique KH (2012). Micronutrient application through seed treatments: a review. J Soil Sci Plant Nutr 12(1): 125-142.

8. Tripathi DK, Singh S, Mishra S, Chauhan DK \& Dubey NK (2015). Micronutrients and their diverse role in agricultural crops: advances and future prospective. Acta Physiol Plant 37(7): 139.

9. Tiwari M, Kumar M, Yadav R \& Jain U (2015). Impact of Heavy Metals (Copper and Zinc) On Seed Germination and Seedling Growth in Vigna mungo L. Hepper Var. Azad-3 (KU-96-3). Life Sci Leaflets. 65: 55.

10. Mondal S \& Bose B (2019). Impact of micronutrient seed priming on germination, growth, development, nutritional status and yield aspects of plants. J Plant Nutr 42(19): 2577-2599.

11. Manivasagaperumal $\mathrm{R}$, Balamurugan $\mathrm{S}$, Thiyagarajan G \& Sekar J (2011). Effect of zinc on germination, seedling growth and biochemical content of cluster bean (Cyamopsis tetragonoloba (L.) Taub). Current Bot 2(5): 11-15.

12. Beauchamp C \& Fridovich I (1971). Superoxide dismutase: Improved assays and an assay applicable to acrylamide gels. Anal Biochem 44(1): 276-287.

13. Vetter JL, Steinberg MP \& Nelson AI (1958). Enzyme assay, quantitative determination of peroxidase in sweet corn. $J$ Agric Food Chem 6(1): 39-41.

14. Kumar PP, Kumaravel S \& Lalitha C (2010). Screening of antioxidant activity, total phenolics and GC-MS study of Vitex negundo. Afr J Biochem Res 4(7): 191-195.

15. Arnon DA (1949). Copper enzymes in isolated chloroplasts. polyphenoloxidase in Beta vulgaris. Plant Physiol 24: 1-15.

16. Bates LS, Waldren RP \& Teare ID (1973). Rapid determination of free proline for water-stress studies. Plant and Soil 39(1): 205-207.

17. Singleton VL, Orthofer R \& LamuelaRaventós RM (1999). Analysis of total phenols and other oxidation substrates and 
antioxidants by means of folin-ciocalteu reagent. In Methods in Enzymol 299: 152178.

18. Zhishen $\mathrm{J}$, Mengcheng $\mathrm{T} \&$ Jianming $\mathrm{W}$ (1999). The determination of flavonoid contents in mulberry and their scavenging effects on superoxide radicals. Food Chem 64(4): 555-559.

19. Lowry OH, Rosebrough NJ, Farr AL \& Randall RJ (1951). Protein measurement with the Folin phenol reagent. $J$ Biol Chem 193: 265-275.

20. Jamil M, Deog Bae L, Kwang Yong J, Ashraf M, Sheong Chun L \& Eui Shik R (2006). Effect of salt $(\mathrm{NaCl})$ stress on germination and early seedling growth of four vegetables species. $J$ Cent Eur Agric 7(2): 273-282.

21. Bojović B, Đelić G, Topuzović M \& Stanković M (2010). Effects of $\mathrm{NaCl}$ on seed germination in some species from families Brassicaceae and Solanaceae. Kragujevac J of Sci 32: 83-87.

22. Jeannette S, Craig R \& Lynch JP (2002) Salinity tolerance of phaseolus species during germination and early seedling growth, Crop Sci 42: 1584-1594

23. Farooq MS, Basra SM \& Ahmad N (2007). Improving the performance of transplanted rice by seed priming. Plant Growth Regul 51(2): 129-137.

24. Raj AB, Raj SK, Prathapan K \& Radhakrishnan NV (2019). Nutripriming with zinc sulphate and borax for early growth and seedling vigour in grain cowpea [Vigna unguiculata (L.) Walp]. Legume ResAn Inter J 43(2): 258-262.

25. Ajouri A, Asgedom H \& Becker M (2004). Seed priming enhances germination and seedling growth of barley under conditions of $\mathrm{P}$ and $\mathrm{Zn}$ deficiency. J Plant Nutr Soil Sci 167(5): 630-636.

26. Omer S \& Singh A (2019). Adsorption properties of Biomass Ash/Graphene Oxide Composite for the Removal of Copper from Industrial Waste Water. J Appl Life Sci 2(1): $1-4$.

27. Solanki R \& Dhankhar R (2011). Zinc and copper induced changes in physiological characteristics of Vigna mungo (L.). $J$ Environ Biol 32(6): 747.
28. Kalaikandhan R, Vijayarengan P, Sivasankar R \& Mathivanan S. (2014). The effect of copper and zinc on the morphological parameters of Sesuvium portulacastrum L. Inter J Curr Res Acad Rev 2: 105-20.

29. Koca H, Bor M, Özdemir F \& Türkan İ. (2007). The effect of salt stress on lipid peroxidation, antioxidative enzymes and proline content of sesame cultivars. Environ Exp Bot 60(3): 344-351.

30. Mohammed AH (2007). Physiological aspects of mungbean plant (Vigna radiata $\mathrm{L}$. Wilczek) in response to salt stress and gibberellic acid treatment. Res J Agr Biol Sci 3: 200-213.

31. Ahmad MS, Hussain MU, Ijaz SA \& Alvi AK (2008). Photosynthetic performance of two mung bean (Vigna radiata) cultivars under lead and copper stress. Inter J Agric Biol 10: 167-172.

32. Vaillant N, Monnet F, Hitmi A, Sallanon H \& Coudret A (2005). Comparative study of responses in four Datura species to a zinc stress. Chemosphere 59(7): 1005-1013.

33. Bibi M \& Hussain M (2005). Effect of copper and lead on photosynthesis and plant pigments in black gram [Vigna mungo (L.) Hepper]. B Environ Contam Tox 74(6): 1126-1133.

34. Yasar F, Ellialtioglu S \& Yildiz K (2008). Effect of salt stress on antioxidant defense systems, lipid peroxidation, and chlorophyll content in green bean. Russ J Plant Physl 55(6): 782.

35. Weisany W, Sohrabi Y, Heidari G, Siosemardeh A \& Ghassemi-Golezani K (2012). Changes in antioxidant enzymes activity and plant performance by salinity stress and zinc application in soybean (Glycine max L.). Plant Omics 5(2): 60.

36. Arif M, Shehzad MA, Bashir F, Tasneem M, Yasin G \& Iqbal M (2012). Boron, zinc and microtone effects on growth, chlorophyll contents and yield attributes in rice (Oryza sativa L.) cultivar. Afr J Biotechnol 11(48): 10851-10858.

37. Jamil M, Deog Bae L, Kwang Yong J, Ashraf M, Sheong Chun L \& Eui Shik R (2006). Effect of salt $(\mathrm{NaCl})$ stress on germination and early seedling growth of 
four vegetables species. J Cent Eur Agric 7(2): 273-282.

38. Farooq M, Wahid A \& Siddique KH (2012). Micronutrient application through seed treatments: a review. J Soil Sci Plant Nutr 12(1): 125-142.

39. Reda F, Abdelhamid MT \& El-Lethy SR (2014). The role of $\mathrm{Zn}$ and B for improving Vicia faba L. tolerance to salinity stress. Middle East J Agric Res 3: 707-714.

40. Tantawy AE (2007). Effect of some mineral and organic compounds on salinity tolerance in tomato (Doctoral dissertation, Ph. D. thesis. Fac Agric Al Azhar Univ).

41. Salama YA, Nagwa MK, Saleh SA \& Zaki MF (2012). Zinc ameliorative effects on tomato growth and production under saline water irrigation conditions. Res $J$ Appl Sci 8(12): 5877-5885.

42. Wang Y, Wisniewski M, Meilan R, Cui M, Webb R \& Fuchigami L (2005). Overexpression of cytosolic ascorbate peroxidase in tomato confers tolerance to chilling and salt stress. J Am Soc Hortic Sci 130(2): 167-173.

43. Poschenrieder CH \& Barceló J (1999). Water relations in heavy metal stressed plants. In Heavy metal stress in plants. Springer, Berlin, Heidelberg. pp. 207-229.

44. Song CZ, Liu MY, Meng JF, Chi M, Xi ZM \& Zhang ZW (2015). Promoting effect of foliage sprayed zinc sulfate on accumulation of sugar and phenolics in berries of Vitis vinifera cv. Merlot growing on zinc deficient soil. Mol 20(2): 2536-2554.

45. Shinde P, Doddagoudar SR \& Vasudevan SN (2017). Influence of seed polymer coating with micronutrients and foliar spray on seed yield of chickpea (Cicer arietinum L.). Legume Res 40(4): 704-709.

46. Dos Santos WD, Maria de Lourdes LF, Finger A, Teixeira AC \& Ferrarese-Filho O (2004). Lignification and related enzymes in
Glycine max root growth-inhibition by ferulic acid. J Chem Ecolo 30(6): 12031212.

47. Tavallali V, Rahemi M, Eshghi S, Kholdebarin B \& Ramezanian A (2010). Zinc alleviates salt stress and increases antioxidant enzyme activity in the leaves of pistachio (Pistacia vera L., 'Badami') seedlings. Turk J Agric For 34(4): 349-359.

48. Sarwar N, Bibi S, Ahmad M \& Ok YS (2014). Effectiveness of zinc application to minimize cadmium toxicity and accumulation in wheat (Triticum aestivum L.). Environ Earth Sci 71(4): 1663-1672.

49. Sahin U, Ekinci M, Ors S, Turan M, Yildiz S \& Yildirim E (2018). Effects of individual and combined effects of salinity and drought on physiological, nutritional and biochemical properties of cabbage (Brassica oleracea var. capitata) Sci Horticul 240: 196-204.

50. Batool A, Ashraf M, Akram NA \& AlQurainy F (2013). Salt-induced changes in the growth, key physicochemical and biochemical parameters, enzyme activities, and levels of non-enzymatic antioxidants in cauliflower (Brassica oleracea L.). J Hortic Sci Biotech 88(2): 231-241.

51. Molazem D \& Bashirzadeh A (2015). Impact of salinity stress on proline reaction, peroxide activity, and antioxidant enzymes in maize (Zea mays L.). Pol J Environ Stud 24(2): 597-603.

52. Zhao ZQ, Zhu YG, Kneer R \& Smith SE (2005). Effect of zinc on cadmium toxicityinduced oxidative stress in winter wheat seedlings. J Plant Nutr 28(11): 1947-1959.

53. Cherif J, Mediouni C, Ammar WB \& Jemal $F$ (2011). Interactions of zinc and cadmium toxicity in their effects on growth and in antioxidative systems in tomato plants (Solarium lycopersicum). $J$ Environ Sci 23(5): 837-844. 